REVIEW

\title{
Documenting the biogeographic history of Microtus cabrerae through
} its fossil record

César LAPLANA Museo Arqueológico Regional, Pza. Bernardas s/n 28801 Alcalá de Henares (Madrid), Spain. E-mail: cesar.laplana@gmail.com

Paloma SEVILLA Departamento de Paleontología, Facultad de Ciencias Geológicas (UCM), C/ José Antonio Novais 2, 28040 Madrid, Spain. E-mail: psevilla@geo.ucm.es

\begin{abstract}
1. Microtus cabrerae is an Iberian endemic vole species with specific adaptations to the subhumid mediterranean climate. Its living populations are under a regressive trend. The earliest known records of Microtus cabrerae date from the late Middle Pleistocene, and it originated from Microtus brecciensis.

2. We describe changes in the geographic distribution of Microtus cabrerae throughout its history based on its palaeontological record, and to link them to environmental changes that have taken place since the appearance of Microtus cabrerae.

3. A series of successive chronological intervals comprising the recorded existence of the species was established, so that the majority of the published fossil records of Microtus cabrerae could be used for analysis. For each interval, a map with the inferred distribution of the species was created. The maps were used to establishing variations in the species' distribution through time.
\end{abstract}


4. A first regression in the extent of the distribution of Microtus cabrerae took place in Marine Isotope Stage 2, when the species abandoned south-eastern France and central Spain, where it had been present since the beginning of the Late Pleistocene. This range contraction was probably due to the global decline in temperatures and rainfall that took place in this period. After a rapid recolonisation of most of the previously abandoned areas at the beginning of the Holocene, and a remarkable increase in records during the Neolithic, a new gradual decrease of records is observed from the Neolithic to the Roman period, intensifying from ca. 2000 years ago onwards, and ending with the final disappearance of the species from south-western France and north-eastern Iberia. This second decline is linked to the aridification of the Mediterranean entourage that started in the mid-Holocene and has been enhanced by human modification of the landscape. The species is shown to be sensitive to climate change.

Key words: Holocene Climatic Optimum, Iberian Peninsula, Last Glacial Maximum, post-glacial recolonization, southern France.

\section{INTRODUCTION}

Cabrera's vole Microtus cabrerae is a stout vole included in the monotypic subgenus Iberomys. The species recently originated from Microtus brecciensis, probably during the late Middle Pleistocene. It is presently endemic to the Iberian Peninsula (Spain and Portugal), where it occupies areas with subhumid climates within the Supra-, Meso- and Thermomediterranean bioclimatic zones of Rivas-Martínez's (1981) Bioclimatic 
Classification System, though it also occupied areas of southern France in the past. Its ancestral species Microtus brecciensis was also distributed in the Italian Peninsula, and possibly also in the Balkan Peninsula (Vuletic 1953). Iberian populations of Microtus cabrerae are under range contraction (Fernández-Salvador 2007), and the species is classified as 'near threatened' in the International Union for Conservation of Nature's Red List of Threatened Species.

Microtus cabrerae is a typically Mediterranean species which is specifically adapted to withstand high summer temperatures. It has the ecophysiological ability to increase its body temperature moderately when ambient temperatures are high, thus reducing its metabolic expense due to thermoregulation under these circumstances (Mathias et al. 2003). However, it is not found in areas with arid mediterranean climates characterised by long summer droughts, since water scarcity strongly interferes with its reproduction and development (Fernández-Salvador et al. 2005). This species occurs mainly at medium altitudes, in brushwood near small streams, in riverside areas with sedges or rushes, or in fields of tall grass, and is frequently associated with oak Quercus spp. woods (Niethammer et al. 1964, Ayarzagueña \& Lopez-Martinez 1976, Madureira \& Ramalhinho 1981, San Miguel Ayanz 1992, Pita et al. 2006, Santos et al. 2006). Microtus cabrerae has a ' $\mathrm{K}$ ' reproductive strategy (Fernández-Salvador et al. 2001), which together with its strict habitat specialisation, makes it extremely sensitive to environmental changes. Because of these features, Microtus cabrerae is an important ecological indicator when reconstructing past environments in the sites where its fossil remains are found. 
We aim to reconstruct the biogeographic history of Microtus cabrerae from its fossil record in archaeological and palaeontological sites. Previous research has highlighted changes in the species' distribution over time, but was based on few data (Ayarzagüeña \& López Martínez 1976, Cabrera-Millet et al. 1983, López-Martínez 2009, GarridoGarcía \& Soriguer-Escofet 2012). We used every available record of the species found in the literature, throughout its whole geographic range and from its first appearance to the present, as well as a number of unpublished records from Spanish localities. The records we used extend through France, Portugal, Gibraltar (a British overseas territory) and Spain, and allowed us to reconstruct with considerable precision the biogeographic changes undergone by Microtus cabrerae during its history. The successive changes that have taken place in the past provide a basis for a better understanding of the species' current geographic retraction, enabling us to establish whether this started recently or is part of a long-term process, and to explore and understand the causes of the recent regressive trend of Microtus cabrerae.

\section{METHODS}

A thorough review of published records of Microtus cabrerae in the Late Pleistocene and Holocene of the Iberian Peninsula and southern France was conducted. The papers containing relevant data are extremely varied; many are local publications or monographs dedicated to a particular site, and are of limited distribution and thus difficult to obtain. A complete list of publications dealing with fossil records of Microtus cabrerae is given in Appendix S1. A total of 134 records of Microtus cabrerae from over 100 localities was obtained, 62 of which refer to the Late Pleistocene (Appendix S2) and 72 to the Holocene (Appendix S3). Three unpublished 
records from Spanish Iberian Holocene sites, from the mesolithic levels of Cueva del Conejar (Cáceres), the neolithic levels of Cueva de Chaves (Huesca) and from the late Roman site of Valdetorres de Jarama (Madrid), were included. We excluded a few published records that did not provide a sufficiently precise age to be allocated to one of the chronological intervals we used in analysis.

To quantify variations in the geographic distribution of the species through time, two major time intervals comprising the whole of the species' temporal duration were considered: the Late Pleistocene and the Holocene. Within each, secondary subdivisions were defined. For the Late Pleistocene, in which fossil records of the species are less numerous, intervals of longer duration coinciding with Marine Isotope Stages (MIS) 2, 3 and 5-4 were used (MIS5 and 4 were pooled because of the short duration of MIS4). For the Holocene, in which records of Microtus cabrerae are abundant, shorter time intervals were defined based on the succession of archaeological cultural complexes (Fig. 1). Though the time intervals differ in duration, the criteria chosen to establish them make it possible to use most published records of Microtus cabrerae with the corresponding ages provided in the papers. This was necessary since information concerning the chronology of the sites is widely heterogeneous (biochronology is used in palaeontological sites, chronocultural data in archaeological sites, chronoclimatic stages or numerical dates obtained through different techniques are used in other sites), and since otherwise it would be impossible to bring together all the available information and build from it a global pattern.

In order to make recent and past distributions of the species easy to compare, the available records were plotted for each time interval using the topographic base of the 
Atlas of European Mammals (Mitchell-Jones et al. 1999), divided in 50x50 km Universal Transverse Mercator squares. The recent distribution of Microtus cabrerae has been updated using the most recent data provided by Rosario and Mathias (2007), Mira et al. (2008) and Pita et al. (2010) for Portugal, and by Fernández-Salvador (2007), Garrido-García et al. (2008) and Ortuño (2009) for Spain.

\section{LIMITATIONS}

Five main factors were found to constrain the spatial and chronological significance of our analysis of the biogeographic evolution of Microtus cabrerae derived from the study of its archaeological and palaeontological record, by affecting the density of records:

1 - The age of the site. The number of localities where Microtus cabrerae is recorded is higher in more recent sites than in those with older chronology, to the point that the few available records for the species during the Late Pleistocene hinder the recognition of patterns of variation in its geographic distribution at the very beginning of its evolutionary history. However, this is not the only factor determining the density of records of Microtus cabrerae through time (see limitation 4).

2 - Regional geology. Over 90\% of Pleistocene and Holocene archaeological and palaeontological sites with microvertebrate fossils are located in the karsts of calcareous formations. These rocks outcrop mainly in mountain chains of alpine origin (Pyrenees, Iberian System, Central System, Catalan Coastal Range, Betic Range, the Alps), and as 
a consequence, the probability of finding fossils of Microtus cabrerae outside these environments is considerably lower.

3 - Levels of interest in the study of small mammal fossils depending on tradition. In south-eastern France there is a long tradition of studying Pleistocene and Holocene small mammals, but the amount of available data from Spanish regions is highly variable (see López-García et al. 2011a). This is partly due to variations in research strategies: some researchers have focussed on geographically close sites, other sites have been studied less.

4 - Levels of interest in the study of small mammal fossils depending on the chronology of sites. Small mammals are considered a valuable tool for chronological and environmental interpretations in Pleistocene and most Holocene sites. However, in more recent sites their value is comparatively lower, since alternative dating methods can provide more precise results (radiocarbon dating, ceramics, etc.) and a wider choice of sources for environmental reconstructions exists. Consequently, in protohistoric and historic sites less effort is made to obtain small mammal fossils, and fewer data are available.

5 - Human modification of environments close to the sites. Human populations are known to have modified natural environments, particularly in historic times. Modifications in the areas surrounding human settlements have driven wild species out and favoured the presence of commensal species. For this reason, data on noncommensal small mammals are particularly scarce in historic periods. 
All these factors contribute to the uneven spatial and temporal distribution of sites with Microtus cabrerae remains, and affect the interpretation of our results. Concerning the geographic origin of the data, the regions with a more complete record are located in south-eastern France and eastern and north-eastern Iberia, and to a lesser extent, central and southern Spain. With regards to chronology (Fig. 2), records from the Late Pleistocene are scarce, though a slight increase is observed at the end of this period. During the Holocene the number of records increases considerably until the Bronze Age, from then onwards records become extremely rare and are practically restricted to southern France. Since the Roman Period, no records of Microtus cabrerae are found in sites where precise dates are available; some are available from southern France (Heim de Balsac 1939, Jeannet 1979, Paunesco \& Brunet-Lecomte 2005) and though lacking any sort of age reference, were considered to be very recent, practically present-day, by the authors.

\section{CHANGES IN THE GEOGRAPHIC DISTRIBUTION OF MICROTUS CABRERAE IN THE LATE PLEISTOCENE AND HOLOCENE}

Microtus cabrerae probably originated from its ancestor Microtus brecciensis during the late Middle Pleistocene. The species differ in morphological and biometric dental features (Ayarzagüeña \& López Martínez 1976, Cabrera-Millet et al. 1983, Povoas et al. 1992, Paunesco \& Brunet-Lecomte 2005); the conspicuously larger size of the descendant species is one of the most relevant. This feature is particularly evident in Iberian populations in which, during the Middle Pleistocene, the mean length of the first lower molar of Microtus brecciensis never exceeds $2.95 \mathrm{~mm}$. The measurement is 
always over $3.04 \mathrm{~mm}$ in Late Pleistocene and Holocene populations of Microtus cabrerae (Table 1). The first records of populations displaying larger molars and assigned to Microtus cabrerae are found in Middle-Late Pleistocene transition localities of southern France. In localities such as Payre (levels G and F, Desclaux et al. 2008) or Baume Moula-Guercy (levels XIV-XIX, Desclaux \& Defleur 1997), representatives of the subgenus Iberomys are present, which because of their large size (first lower molar length $>3.10 \mathrm{~mm}$ ) can be considered to belong to Microtus cabrerae, though they were originally identified as Microtus brecciensis. Levels F and G of Payre have thermoluminiscence dates of $232 \pm 15 \mathrm{kyr}$ BP (thousand years before present) and $231 \pm$ 27 kyr BP respectively, and levels F-G together were dated by Uranium series at $235 \pm$ 18 kyr BP (Falguères et al. 2008). However, according to biochronological criteria based on small mammal assemblages, Desclaux et al. (2008) assign these levels to a slightly younger age: either close to, or even within, the Late Pleistocene $(<130 \mathrm{kyr}$ BP). In Baume Moula-Guercy, level XIV is placed in the Eemian (basal Late Pleistocene) on the basis of its climatic correlation according to the small mammal assemblage, and underlying levels XIX-XV are classed as late Middle Pleistocene (MIS6, Defleur et al. 2001). The rare late Middle Pleistocene records of Iberomys in the Iberian Peninsula (e.g. Bolomor III; Guillem Calatayud 1995), assigned to Microtus brecciensis, are unfortunately not accompanied by adequate data that might help to establish whether this material is Microtus brecciensis or Microtus cabrerae. The only exception is that of Sala de los Huesos (Hanquet 2011). At this site, the small-mammal bearing levels are placed between two stalagmitic plates which were Uranium-thorium dated as $183+14-12 \mathrm{kyr}$ BP (bottom) and $117+17-14 \mathrm{kyr}$ BP (top), so they belong to the end of the Middle Pleistocene (MIS6) or to the very beginning of the Late Pleistocene (MIS5). The Iberomys population from this site displays typical Microtus 
brecciensis size (mean first lower molar length $=2.93 \mathrm{~mm}$ ) and morphology. Taking into account uncertainties related to the age of the first records of Microtus cabrerae in France, if their late Middle Pleistocene age is correct, this should be interpreted as evidence of a French origin for this species. If, on the other hand, they are early Late Pleistocene in age, coinciding with the age of the first Iberian Microtus cabrerae records, this would imply a simultaneous origin of the species in France and in the Iberian Peninsula. These proposals contradict previous interpretations (Garrido-García \& Soriguer-Escofet 2012) which located the centre of origin of Microtus cabrerae in the Iberian Peninsula. Further research focused on obtaining unquestionable and precise dates for the late Middle Pleistocene and early Late Pleistocene Iberian and French sites is needed to clarify the geographical origin of Microtus cabrerae.

During the Middle Pleistocene Microtus brecciensis extended throughout the Iberian Peninsula, with the exception of the Cantabrian region and the North Atlantic facade (Ayarzagüeña \& López Martínez 1976, Cabrera-Millet et al. 1983, López-Martínez 2009), and was found in the southern third of France (Marquet 1993, Jeannet 2000) and in the Italian Peninsula, where records are common (Kotsakis et al. 2003, Sala \& Masini 2007, Sala \& Locatelli 2009). Occasional records from the Balkans are still to be confirmed (Vuletic 1953).

At the beginning of the evolutionary history of Microtus cabrerae, during MIS5-4 and MIS3 (Fig. 3a and b), its distribution coincided with that of Microtus brecciensis except in the Italian Peninsula, where Late Pleistocene or Holocene records are unknown. Therefore Microtus cabrerae never occupied the Italian Peninsula. Although GarridoGarcía and Soriguer-Escofet (2012) consider Microtus cabrerae to have been absent 
from France during the whole of the Late Pleistocene, this is contradicted by the presence of fossils of this age in the central French Pyrenees (Grotte du Noisetier Jeannet, 2001), the eastern margin of the Aquitaine Basin (Coudoulous II - Cochard, 2004), the Rhone Valley (Payre - Desclaux et al. 2008; Baume Moula Guercy Desclaux \& Defleur 1997; Baume Néron - Jeannet, 2000; among others), and the French Mediterranean coast (Grotte du Lazaret - Valensi et al. 2007). In Iberia, records are mainly from the Mediterranean region and central and southern Spain. Between MIS5 and MIS3 no relevant differences in the extent of the area occupied by the species is observed, though a decrease in the frequency of records occurred in France ( 7 records in MIS5, 4 in MIS3). Any effect of climate cooling during MIS4 on the species' distribution is impossible to establish, due to the short duration of the period and because few records of Microtus cabrerae are available from the Late Pleistocene.

In MIS2 (Fig. 3c), an important difference in the general distribution of the species is observed compared to its distribution in the early Late Pleistocene. A visible contraction took place: records are practically restricted to the Iberian Peninsula. One record of Microtus cabrerae from the end of MIS2 is from southern France, from levels 2-3 of Abri Soubeyras (Chaline in Brochier 1977), found in a magdalenian-azilian archaeological context. This biogeographic change is probably related to some environmental constraint such as climate. Bias due to the poor quality of the fossil record in south-eastern France is very unlikely, given the numerous sites with small mammal fossils in this region. The MIS2 was predominantly a cold period which included the Last Glacial Maximum, during which southern Europe and the Mediterranean suffered extremely low temperatures throughout the year, accompanied by dry conditions (Peyron et al. 1998). This cold climate strongly affected the 
distribution of many species in Europe, the southern regions becoming a refuge for many that inhabited northern and central Europe (Sommer \& Nadachowski 2006). Several sections containing sedimentary sequences with small mammals that belong to this time interval show that the absence of Microtus cabrerae coincided with the presence of other species coming from higher latitudes and characteristic of colder climates, such as Dicrostonyx torquatus, Sicista loriger, Citellus superciliosus, Microtus gregalis and Microtus oeconomus. This is the case, for instance, in Grotte de la Salpêtrière (Brandy 1977), Bois des Brousses and Laroque II (Chaline 1981), and in levels 2 and 3 of Grotte de Salpètre and levels 8, 9 and 10 of Balma de l'Abeurador (Marquet 1993). This drop in global temperatures affected species specifically adapted to warm climates, such as Microtus cabrerae, which shifted their northern populations towards more southern regions and disappeared from their northernmost range with the advancing ice. The presence of Microtus cabrerae in the Abri Soubeyras may be interpreted as an early re-colonisation of south-eastern France with Iberian populations, which occurred before the end of MIS2, during an episode of climatic improvement, probably the Allerod oscillation (after Brochier 2004). It might alternatively be evidence of the existence of small isolated refuges for the species in south-eastern France, which escaped detection due to the scarcity of palaeontological records in the area. Proof of the existence of such refuges in southern France is found in MIS2 sediments deposited in the marine platform of the Gulf of Lion, which contain pollen of temperate forest species including deciduous Quercus (Beaudouin et al. 2007).

No records of Microtus cabrerae are associated with the MIS2 in central Iberia. This cannot be considered a consequence of a general lack of small mammal records from this time period, since several sites have abundant and well-represented material not 
including this species. For example, in MIS2 sites in the Sistema Central, such as Peña de Estebanvela (Sesé 2006) and Abrigo del Monte (Sevilla et al. 2009), Microtus cabrerae is not present, but northern species, such as Microtus oeconomus, are part of the assemblages. Microtus cabrerae must have become absent from these Spanish localities when the climate became colder and more arid in central Iberia, which allowed the development of open steppe environments (González-Sampériz et al. 2010). As a consequence, the local Microtus cabrerae populations were driven either to extinction or towards peripheral areas of their distribution mainly in the south, where the majority of the records of this age are located. The Mediterranean or Atlantic influence in these peripheral areas favoured milder environmental conditions, enabling the survival of the species. This situation is particularly evident during the Last Glacial Maximum, when all records of Microtus cabrerae (Gruta do Caldeirao, level H Povoas et al. 1992; Higueral de la Valleja Cave, levels IV-V - Jennings et al. 2009; Sala de las Chimeneas - Bañuls Cardona et al. 2012; Cueva de los Ojos - Fuentes Jiménez 1989; Cueva de Nerja - Cortés Sánchez et al. 2008) are from the southern half of the Iberian Peninsula. The few records of this species in northern Iberia (Cova de l'Arbreda - Alcalde i Gurt 1987; Cova Colomera - López García et al. 2010a; Cueva de Valdavara I - López-García et al. 2011a; Portalón - López-García et al. 2010b) are either earlier, or mainly later than the Last Glacial Maximum, and probably coincided with some of the climatic oscillations towards milder climate which occurred within the MIS2. In this sense, the sequence in the Cova de l'Arbreda is particularly enlightening (Alcalde i Gurt 1987); Microtus cabrerae is absent in all of the lower part of the sedimentary sequence, which represents practically the whole of the MIS2. Only once the post-Solutrean palaeolithic levels are reached does the species appear, where it persists to the top of the sequence with only a few exceptional interruptions. 
After the pronounced retraction of Microtus cabrerae during the MIS2, the species started to spread again at the beginning of the Holocene through south-eastern France, to the point that the majority of the Epipalaeolithic and Mesolithic records of the species (8 out of 12) come from this region (Fig. 3d). Records from La Grotte de l'Abeurador (Hérault, France) document this process of recolonisation of south-eastern France. In this site, Microtus cabrerae is not represented in the lowermost levels, of late Upper Palaeolithic and Azilian age, but starts to appear in the Mesolithic levels (Marquet 1987). This circumstance is clearly linked to the global climatic improvement that took place at the beginning of the Holocene and reached its peak at the Holocene Climatic Optimum (ca. 9000-5000 yr BP). During this climatic phase a rapid recovery of temperate forests took place in Europe (Fletcher et al. 2010). In south-eastern France this period was characterised by the beginning of the recolonisation of the region by deciduous Quercus, which is increasingly represented in anthracological and palynological records (Vernet 1997, Heinz \& Thiébault 1998, Brewer et al. 2002). In contrast, records of Microtus cabrerae from this period in Iberia are extremely rare and dispersed, probably because records of microvertebrates in general have been collected from only a few sites of this age. The lack of records hampers the reconstruction of changes in the geographic distribution of the species.

Records of Microtus cabrerae from the Neolithic are more abundant (Fig. 3e): 28 records of the species were obtained for this time interval, 11 from France (northern slopes of the Pyrenees, margins of the Rhone Valley) and the remainder from Spain, mainly from its eastern half (southern slopes of the Pyrenees, Atlantic and Mediterranean littoral areas and the Sierra de Segura). An isolated record came from 
central Spain (Cueva de la Ventana, Sánchez et al. 2005) and another from the south (Cueva de El Toro, Watson et al. 2004). This particular pattern in Iberia is probably an artefact of the comparatively longer tradition of studies dealing with small vertebrates in eastern Spain. During the Neolithic, which coincides to a large extent with the Holocene Climatic Optimum, Microtus cabrerae re-occupied the area it abandoned during MIS2, regaining a distribution similar to that in the first part of the Late Pleistocene. The frequent records of the species in eastern and north-eastern Iberia and south-eastern France were probably linked to the expansion in these regions of deciduous Quercus, evidenced by several pollen sequences (Pla de l'Estany in Burjachs 1994, Capestang in Jalut 1995, Gulf of Lion in Beaudouin et al. 2005, among others). Thus, the Neolithic seems to be the acme of the evolutionary history of Microtus cabrerae, though earlier periods with limited palaeontological records, such as the Eemian in the early Late Pleistocene, may have been favourable for the species.

During the Chalcolithic-Bronze Age (Fig. 3f) the distribution of Microtus cabrerae remained similar to that in the previous time interval, although with some slight differences. Like records from the Neolithic, records from this period are concentrated in southern France and in north-eastern Iberia, but isolated records occur in other areas of the Iberian Peninsula: in the south-east (both in coastal and interior areas), in the littoral regions of southern and western Portugal, and in north-western Iberia. Again, the lack of records in central Spain is probably caused by the lack of tradition in the study of small vertebrate fauna, rather than by the absence of the species. Nevertheless, lower numbers of records are observed than in previous periods. This is partly due to the lower relevance given to small mammal studies in protohistoric contexts, the diminishing interest given to this fauna in younger sites, and environmental changes 
caused by both climate and human activities that ultimately affect the species' distribution. After the Holocene Climatic Optimum, the climate in the Mediterranean region became drier (Burjachs et al. 2000, Jalut et al. 2000, Pantaleón-Cano et al. 2003, Pérez-Obiol et al. 2011). This increased the human impact on the environment, led to a gradual decrease in the area covered by forests, and resulted in the xerification of landscapes in the Iberian Peninsula and south-eastern France (Heinz \& Thiébault 1998; Fierro Enrique et al. 2011). According to climatic models based on pollen data, the establishment of a dry mediterranean climate in the Iberian Peninsula started in the south and advanced gradually towards the north during the Holocene (Jalut et al. 2000), so that the recent xeric conditions first appeared in southernmost Iberia. Consequently, habitats potentially favourable for Microtus cabrerae gradually retracted and disappeared from the south towards the north. Thus, from this period to the present no more records of Microtus cabrerae are found in southernmost Iberia, where the species was well represented during MIS2-3 (e. g., Gibraltar sites, see López-García et al. 2011b; Price 2012; see Fig. 3).

The decreasing trend intensified during the Iron Age - Roman period (Fig. 3g), when the records of Microtus cabrerae become quite rare and finally, during the Middle Ages (Fig. 3h), practically nonexistent. Again, the few records are found mainly in France; in Spain only three isolated records are known, one in the north-east, one in the east and one in central Spain. This scarcity of records in the Iberian Peninsula is mainly because studies of microfauna in archaeological sites of this age onwards are rarely conducted. Additionally, these sites are mostly human settlements with highly anthropized surroundings, where the presence of wild species is hardly to be expected because of competitive displacement by commensal or more tolerant species. 
It is striking that Microtus cabrerae maintained a relatively important representation in southern France and north-eastern Spain until so late a date, though it is now definitely absent there. This is consistent with a very recent disappearance of the species in the area. The most recent records of Microtus cabrerae in France come from levels dated as 1900-2000 yr BP from the city of Lattara (Poitevin et al. 2005) and of medieval levels from Abri de l'Église (Jeannet 1988); other records considered to be subrecent (Heim de Balsac 1939, Jeannet 1979, Paunescu 2001) are lacking precise dates or context to establish their age. In north-eastern Iberia the youngest record is found in the site of Alorda Park, in levels dated as 2400-2300 yr BP (Valenzuela et al. 2009). All these recent data are evidence of the minimum recent persistence of the species in these areas, indicating that Microtus cabrerae was still to be found there at least 2000-1000 years ago.

The reasons for the recent disappearance of Microtus cabrerae from south-eastern France and north-eastern Iberia, and from other regions in the Iberian Peninsula such as the Levante littoral region, where it was also found during the Iberian period (Els Estrets-Racó de Rata, Vilafamés, Castellón; Guillem Calatayud 2011), have been debated in the literature. While some authors (e.g. López-Martínez 2003) linked the contraction of the area occupied by Microtus cabrerae with the climatic change towards aridification that occurred from the middle Holocene onwards, other authors see the contraction as a consequence of anthropic changes in the environment (mainly the expansion of agriculture; Cabrera-Millet et al. 1983, Garrido-García \& Soriguer-Escofet 2012). In our opinion, it seems likely to be the combined result of both climatic and anthropic factors. As previously pointed out, Microtus cabrerae is a markedly specialist 
vole, adapted to humid mediterranean environments. As a consequence of the gradual aridification of the climate in the Mediterranean from the middle Holocene to the present, environments sufficiently humid for Microtus cabrerae survival have been reduced in their extent and have become more dependent on local factors (existing, for example, in areas with a high phreatic level providing humid conditions throughout the year, or in mountain foothills where rainfall is relatively higher than in surrounding regions). However, many relatively humid areas have been highly modified by human activities, such as continued agriculture and farming, clearing of forests with fires, or wetland draining (Pita et al 2007, Rosário and Mathias 2007), which have reduced the areas occupied by the species and may ultimately drive it to local extinction. This process is still going on, and a clear regression in taking place in Iberian populations; their range is smaller now than it was a few decades ago (Fernández Salvador 2007). A similar regressive pattern is observed in other small mammals adapted to humid environments. For instance, the lesser white-toothed shrew Crocidura suaveolens was found throughout the Levante coast during the Iron Age (Guillem Calatayud 2011), but is no longer found there.

\section{CONCLUSIONS}

Because of its particular ecological requirements, Microtus cabrerae is extremely sensitive to the environmental changes that have taken place during its evolutionary history, and has expanded and contracted its area of distribution accordingly. It has always been of restricted amplitude, extending at its most favourable periods through the southern third part of France, and preferring to occupy the Mediterranean region and 
the Iberian Peninsula with the exception of its north-western Atlantic strip and the Cantabrian region.

Several factors constrain the extent and precision of studies aimed at reconstructing changes in species' distribution patterns during the Late Pleistocene and Holocene. The unequal density of information is mainly a consequence of regional geology features (the presence of calcareous substrates with possibilities of karstification) and of the existence of locally biased interest in studies of small mammal fossils. The frequency of records through history also varies irregularly: on one hand, more sites of younger age are available, but on the other, small mammal fossils found in older sites (prehistoric and protohistoric) are more interesting to researchers and so have been documented more. The relatively reduced applicability of small mammals in historic sites may explain the low numbers of published data, which may be further exacerbated by the expected lower representation of wild animals relative to commensal species in humanmodified environments.

For all these reasons, the palaeontological and archaeological documentation of Microtus cabrerae from a geographical point of view is more complete and robust in south-eastern France, whereas data from the Iberian Peninsula are concentrated in discontinuous areas, mainly in the eastern, southern and central part of Iberia. Data from the west and the remaining interior regions are rare. From a chronological point of view, data increase in number from the earliest Late Pleistocene to the Holocene, are particularly abundant during the Neolithic, and from that moment onwards decrease, becoming practically nonexistent in historic times. 
According to the available data, the palaeontological and archaeological record of Microtus cabrerae shows two distinct retraction events in its geographic range. In the first, which took place during MIS2, Microtus cabrerae disappeared from the areas it had previously occupied north of the Pyrenees and in the mountain areas of central Spain, taking refuge in southern Iberia. In the final part of MIS2, a recovery in the species' distribution occurred, shown by a few records in the north of Iberia and southern France. The second retraction event probably started in the middle Holocene and has increased in intensity during the past 2000 years. It is still going on, and as a consequence Microtus cabrerae is no longer found in south-eastern France or in northeastern and southernmost Spain.

The reason for the first retraction event, which took place during MIS2, was clearly the change in climate towards dominant colder and drier conditions. The reason for the second retraction event was a combination of change in climate towards more arid conditions in the Mediterranean, and increasing human pressure on natural environments. In the interval between the two retraction events, during the Neolithic, the species reached its highest frequency of records, coinciding with the second half of the Holocene Climatic Optimum. At this time, the prevailing high temperatures and abundant rainfall increased the areas available for the species and led to its acme. It is equally possible that a peak in population density occurred earlier in the species' evolutionary history because of similar favourable conditions, for instance during the Eemian (earliest Late Pleistocene), but the scarcity of records from the beginning of the Late Pleistocene does not help to corroborate this hypothesis.

\section{ACKNOWLEDGEMENTS}


This research was part of project S2010/BMD-2330, which was funded by the I+D activities program for research groups of the Consejería de Educación of the Community of Madrid. The authors have additional support from projects CGL201238358 and UCM-910607. M. A Galindo-Pellicena allowed us to include her unpublished data about the presence of Microtus cabrerae in Chaves Cave.

\section{REFERENCES}

Alcalde i Gurt G (1987) Els rosegadors del paleolitic superior de la Cova de l'Arbreda (Serinyá, Catalunya). Significació paleoecològica y paleoclimàtica. Cypsela 6: 89-96.

Ayarzagüeña J, López Martínez N (1976) Estudio filogenético y comparativo de Microtus cabrerae y Microtus brecciensis. Doñana, Acta Vertebrata 3: 181-204.

Bañuls Cardona S, López-García JM, Blain H-A, Canals Salomó A (2012) Climate and landscape during the Last Glacial Maximum in southwestern Iberia: The smallvertebrate association from the Sala de las Chimeneas, Maltravieso, Extremadura. Comptes Rendus Palevol 11: 31-40.

Beaudouin C, Suc J-P, Acherki N, Courtois L, Rabineau M, Aloïsi J-C, Sierro, FJ, Oberlin C (2005) Palynology of the nortwestern Mediterranean shelf (Gulf of Lions): First vegetational record for the last climatic cycle. Marine and Petroleum Geology 22: 845-863. 
Beaudouin C, Jouet G, Suc J-P, Bernié S, Escarguel G (2007) Vegetation dynamics in southern France during the last $30 \mathrm{ky}$ BP in the light of marine palynology. Quaternary Science Reviews 26: 1037-1054.

Brandy LD (1977) Les rongeurs de quelques grottes du Würm récent et du Postglaciaire, en Provence et en Languedoc. Supplément du Bulletin de l'Association Française pour l'Étude du Quaternaire 47: 347-351.

Brewer S, Cheddadi R, de Beaulieu JL, Reille M., data contributors (2002) The spread of deciduous Quercus throughout Europe since the last glacial period. Forest Ecology and Management 156: 27-48.

Brochier JE (1977) Évolution des climats et des paysages vauclusiens au cours du Würmien récent et du Postglaciaire. Paléoecologie de l'Homme Fossile 1, Éditions du Centre National de la Recherche Scientifique, Marseille, France.

Brochier JE (2004) L'Abri de Soubeyras et les paysages tardiglaciaires dans le bassin du Calavon. In: Buisson-Catil J, Guilcher A, Hussy C, Olive M, Pagni M (eds) Vaucluse Préhistorique, le Territoire, les Hommes, les Cultures et les Sites, 102. Éditions Barthélemy, Le Pontet, France.

Burjachs F (1994) Palynology of the Upper Pleistocene and Holocene of the north-east Iberian Peninsula: Pla de l'Estany (Catalonia). Historical Biology 9: 17-33. 
Burjachs F, Febrero A, Rodríguez-Ariza MO, Buxó R, Araus JL, Julià R (2000) Holocene pollen sequences and carbon isotope discrimination of plant remains in Spain: evidence of a progressive increase in aridity. In: Balabanis P, Peter D, Ghazi A, Tsogas M (eds) Mediterranean Desertification Research Results and Policy Implications. Proceedings of the International Conference 29 October to 1 November 1996, Crete, Greece. Volume 2, Summary of project results, 11-20. European Commission, Directorate-General Research, Luxembourg.

Cabrera-Millet M, López-Martínez N, Michaux J (1983) Un exemple de lignée endémique iberoccitane, les campagnols Microtus brecciensis et Microtus cabrerae (Mammalia, Rodentia): étude phylogénétique et contexte écologique d'un phénomène évolutif récent. In: Buffetaut E, Mazin JM Salomon E (eds) Actes du Symposium Paléontologique Georges Cuvier, 525-538. Montbéliard, France.

Chaline J (1981) Les Faunes de Rongeurs du Pléistocène Terminal en Languedoc Oriental. Études Quaternaries Languedociennes, número spécial, Excursion de l'Association Française pour l'Étude du Quaternaire: 29-35.

Cochard D (2004) Les Leporidés dans la Subsistence Paléolitique du Sud de la France. $\mathrm{PhD}$ thesis, Université Bourdeaux I, Bordeaux, France.

Cortés-Sánchez M, Morales-Muñiz A, Simón-Vallejo MD, Bergadà-Zapata MM, Delgado-Huertas A, López-García P et al. (2008) Palaeoenvironmental and cultural dynamics of the coast of Málaga (Andalusia, Spain) during the Upper Pleistocene and early Holocene. Quaternary Science Reviews 27: 2176-2193. 
Defleur A, Crégut-Bonnoure É, Desclaux E, Thinon M (2001) Présentation paléoenvironnementale du remplissage de la Baume Moula-Guercy à Soyons (Ardèche): implications paléoclimatiques et chronologiques. L'Anthropologie 105: 369-408.

Desclaux E, Defleur A (1997) Étude préliminaire des micromammifères de La Baume Moula-Guercy à Soyons (Ardèche, France). Systématique, biostratigraphie et paléoécologie. Quaternaire 8: 213-223.

Desclaux E, El Hazzazi N, Villette P, Dubar M (2008) Le contexte environnemental des occupations humaines. L'apport de la microfaune, des restes aviaires et de la malacofaune. In: Moncel M-H (ed.) Le site de Payre: Occupations Humaines dans la Vallée du Rhône à la fin du Pléistocène Moyen et au début du Pléistocène Supérieur, Mémoires de la Société Préhistorique Française 46: 91-105.

Falguères C, Bahain J-J, Masaoudi H (2008) Datation de restes paléontologiques par combinaison des méthodes de la résonance de spin électronique et des séries de l'uranium (méthode ESR/U-Th combinée). In: Moncel M-H (ed.) Le Site de Payre: Occupations Humaines dans la Vallée du Rhône à la fin du Pléistocène Moyen et au début du Pléistocène Supérieur, Mémoires de la Société Préhistorique Française 46: $110-112$.

Fernández Salvador R (2007) Microtus cabrerae Thomas 1906. In: Palomo LJ, Gisbert J, Blanco JC (eds), 429-433. Atlas y Libro Rojo de los Mamíferos Terrestres de España. Ministerio de Medio Ambiente, Madrid, Spain. 
Fernández-Salvador R, García-Perea R, Ventura J (2001) Reproduction and postnatal growth of the Cabrera vole, Microtus cabrerae, in captivity. Canadian Journal of Zoology 79: 2080-2085.

Fernández-Salvador R, García-Perea R, Ventura J (2005) Effect of climatic fluctuations on body mass of a Mediterranean vole, Microtus cabrerae. Mammalian Biology 70: 7383.

Fierro Enrique E, Munuera Giner M, Fernández Jiménez S, Arribas Herrera A, Carrión García JS (2011) Cambios en el paisaje vegetal de la región andaluza durante el Pleistoceno Superior y Holoceno. Menga 2: 15-33.

Fletcher WJ, Sánchez-Goñi MF, Allen JRM, Cheddadi R, Combourieu-Nebout N, Huntley B et al. (2010) Millenial-scale variability during the last glacial in vegetation records from Europe. Quaternary Science Reviews 29: 2839-2864.

Fuentes Jiménez JM (1989) Roedores del yacimiento solutrense "Cueva de los Ojos" (Cozvíjar, Granada). Resúmenes de las V Jornadas de Paleontología, Valencia, Spain.

Garrido-García JA, Soriguer RC, Pérez-Aranda Serrano D, Pardávila X (2008) A revision of the distribution of Cabrera's Vole (Microtus cabrerae Thomas 1906) in Andalusia (Southern Spain). Hystrix 19: 121-131. 
Garrido-García JA, Soriguer-Escofet RC (2012) Cabrera's Vole Microtus cabrerae Thomas, 1906 and the subgenus Iberomys during the Quaternary: Evolutionary implications and conservation. Geobios 45: 437-444.

González-Sampériz P, Leroy SAG, Carrión JS, Fernández S, García-Antón M, GilGarcía MJ, Uzquiano P, Valero-Garcés B, Figueiral I (2010) Steppes, savannahs, forests and phytodiversity reservoirs during the Pleistocene in the Iberian Peninsula. Review of Palaeobotany and Palynology 162: 427-457.

Guillem Calatayud P (1995) Bioestratigrafía de los micromamíferos (Rodentia, Mammalia) del Pleistoceno Medio, Superior y Holoceno del País Valenciano. Saguntum 29: 11-18.

Guillem Calatayud P (2011) Els paisatges ramaders en època ibèrica. Una reconstrucció a partir dels micromamífers. Arqueo Mediterrània 12: 117-121.

Hanquet C (2011) Évolution des Paléoenvironnements et des Paléoclimats au Pléistocène Moyen, en Europe Méridionale, d'après les Faunes de Micromammifères. PhD thesis, Université Montpellier III-Paul Valéry, France.

Heim de Balsac H (1939) Le campagnol denté, rarissime relicte d'un phylum ibérique se retrouve à l'état subfossile en Languedoc. Comptes Rendus Hebdomadaires des Séances de l'Académie des Sciences 209: 123-125. 
Heinz C, Thiébault S (1998) Characterization and palaeoecological significance of archaeological charcoal assemblages during Late and Post-Glacial Phases in Southern France. Quaternary Research 50: 56-68.

Jalut G (1995) Analyse pollinique des sédiments holocénes del'étang de Capestang (Hérault). In: Guilaine J (ed.) Temps et Espace dans le Bassin del'Aude du Néolithique à l'Age du Fer, 293-302. Grands Projets d'Archéologie Métropolitaine, Centre d'Anthropologie, Toulouse, France.

Jalut G, Esteban Amat A, Bonnet L, Gauquelin T, Fontugne M (2000) Holocene climatic changes in the Western Mediterranean, from south-east France to south-east Spain. Palaeogeography, Palaeoclimatology, Palaeoecology 160: 255-290.

Jeannet M (1979) Les rongeurs et l'environnement au Mont des Espelugues (Lourdes, Hautes-Pyrénées). Bulletin de la Société d'Histoire Naturelle de Toulouse 115: 53-64.

Jeannet M (1988) Les rongeurs des niveaux néolithiques de la grotte de Saint-Marcel (Ardèche). Ardèche Archéologie 5: 46.

Jeannet M (2000) Biométrie et écologie de Microtus brecciensis (Mammalia, Rodentia). Revue de Paléobiologie 19: 339-357.

Jeannet M (2001) La microfaune et l'environnement de la grotte du Noisetier à Fréchet (Hautes-Pyrénées). Bulletin de la Société Préhistorique Ariège-Pyrénées 61: 83-91. 
Jennings RP, Giles Pacheco F, Barton RNE, Collcutt SN, Gale R, Gleed-Owen CP et al. (2009) New dates and palaeoenvironmental evidence for the Middle to Upper Palaeolithic occupation of Higueral de Valleja Cave, southern Spain. Quaternary Science Reviews 28: 830-839.

Kotsakis T, Abbazzi L, Angelone C, Argenti P, Barisone G, Fanfani F, Marcolini F, Masini F (2003) Plio-Pleistocene biogeography of Italian mainland micromammals. Deinsea 10:313-342.

López-García JM, Blain H-A, Allué E, Bañuls S, Bargalló A, Martín P et al. (2010a) First fossil evidence of an 'interglacial refugium' in the Pyrenean region. Naturwissenschaften 97: 753-761.

López-García JM, Blain H-A, Cuenca-Bescós G, Ruiz-Zapata MB, Dorado-Valiño M, Gil-García MJ et al. (2010b) Palaeoenvironmental and paleoclimatic reconstruction of the Latest Pleistocene of El Portalón Site, Sierra de Atapuerca, northwestern Spain. Palaeogeography, Palaeoclimatology, Palaeoecology 292: 453-464.

López-García JM, Blain H-A, Cuenca-Bescós G, Alonso C, Alonso S, Vaquero M (2011a) Small vertebrates (Amphibia, Squamata, Mammalia) from the late PleistoceneHolocene of the Valdavara-1 cave (Galicia, northwestern Spain). Geobios 44: 253-269.

López-García JM, Cuenca-Bescós G, Finlayson C, Brown K, Giles Pacheco F (2011b) Palaeoenvironmental and palaeoclimatic proxies of the Gorham's cave small mammal sequence, Gibraltar, southern Iberia. Quaternary International 243: 137-142. 
López Martínez N (2003) La búsqueda del centro de origen en biogeografía histórica. Graellsia, 59: 503-522.

López-Martínez N (2009) Time assymetry in the palaeobiogeographic history of species. Bulletin de la Société Géologique de France 180: 45-55.

Madureira ML, Ramalhinho MG (1981) Notas sobre la distribuçao, diagnose e ecologia dos Insectivora e Rodentia portugueses. Arquivos do Museu Bocage série A, 1: 165-263.

Marquet J-C (1987) Les modifications de l'environnnement postglaciaire en France méditerranéenne d'après les rongeurs de l'Abeurador et de Font-Juvenal. In: Courtin J-C, Roudil J-L, Vernet J-L (eds) Premières Communautés Paysannes en Méditerranée Occidentale, 155-163. Centre National de la Recherche Scientifique, Paris, France.

Marquet J-C (1993) Paléoenvironnement et chronologie des sites du domaine atlantique français d'âge Pléistocène Moyen et Supérieur d'après l'étude des rongeurs. Les Cahiers de la Claise, Suppl. 2: 1-345.

Mathias ML, Klunder M, Santos SM (2003) Metabolism and thermoregulation in the Cabrera vole (Rodentia: Microtus cabrerae). Comparative Biochemistry and Physiology A, 136: 441-446. 
Mira A, Marques CC, Santos SM, Rosario IT, Mathias ML (2008) Environmental determinants of the distribution of the Cabrera vole (Microtus cabrerae) in Portugal: Implications for conservation. Mammalian Biology 73: 102-110.

Mitchell-Jones AJ, Amori G, Bogdanowicz W, Krystufek B, Reijnders PJH, Spitzenberger F, Stubbe J, Thissen JBM, Vohralik V, Zima J (1999) The Atlas of European Mammals. T. and A. D. Poyser Ltd./Societas Europaea Mammalogica, London, UK.

Niethammer J, Niethammer G, Abs M (1964) Ein Beitrag zur Kenntnis der Cabreramaus (Microtus cabrerae Thomas, 1906). Bonner Zoologische Beiträge 15: $127-148$.

Ortuño A (2009) Nuevos datos sobre la distribución del topillo de Cabrera Microtus cabrerae Thomas, 1906 en Murcia. Galemys 21: 71-72.

Pantaleón-Cano J, Yll E-I, Pérez-Obiol R, Roure JM (2003) Palynological evidence for vegetational history in semi-arid areas of the western Mediterranean (Almería, Spain). The Holocene 13: 109-119.

Paunescu A-C (2001) Les Rongeurs du Pléistocène Inférieur et Moyen de Trois Grottes du Sud-est de la France (Vallonet, Caune de l'Arago, Baume Bonne). Implications Systématiques, Biostratigraphiques et Paléoenvironementales. $\mathrm{PhD}$ thesis, Muséum National d'Histoire Naturelle, Paris, France. 
Paunesco AC, Brunet-Lecomte P (2005) Analyse odontométrique du sous-genre Microtus (Iberomys) Chaline, 1972 (Rodentia, Arvicolinae) du sud de la France au Pléistocène moyen et supérieur. Bulletin du Musée d'Anthropologie Préhistorique de Monaco 45: 31-39.

Pérez-Obiol R, Jalut G, Julià R, Pèlachs A, Iriarte MJ, Otto T, Hernández-Beloqui B (2011) Mid-Holocene vegetation and climatic history of the Iberian Peninsula. The Holocene 21: 75-93.

Peyron O, Guiot J, Cheddadi R, Tarasov P, Reille M, de Beaulieu J-L, Bottema S., Andrieu V (1998) Climatic reconstruction in Europe for $18000 \mathrm{yr}$ BP from pollen data. Quaternary Research 49: 183-196.

Pita R, Mira A, Beja P (2006) Conserving the Cabrera vole, Microtus cabrerae, in intensively used Mediterranean landscapes. Agriculture, Ecosystems and Environment, 115: $1-5$.

Pita R, Beja P, Mira A (2007) Spatial population structure of the Cabrera vole in Mediterranean farmland: the relative role of patch and matrix effects. Biological Conservation 134: 383-392.

Pita R, Mira A, Beja P (2010) Spatial segregation of two vole species (Arvicola sapidus and Microtus cabrerae) within habitat patches in a highly fragmented farmland landscape. European Journal of Widlife Research 56: 651-662. 
Poitevin F, Martinez Garcia E, Cassaing J, Sénégas F (2005) Les micromammifères des puits de Lattara. Lattara 18: 307-312.

Povoas L, Zilhao J, Chaline J, Brunet-Lecomte P (1992) La faune de rongeurs du Pleistocène superieur de la Grotte de Caldeirao (Tomar, Portugal). Quaternaire 3: 4047.

Price C (2012) The small mammal fauna of Gorham's Cave. In: Barton RNE, Stringer CB, Finlayson JC (eds) Neanderthals in Context. A report of the 1995-1998 Excavations at Gorham's and Vanguard Caves, Gibraltar. Oxford University School of Archaeology: Monograph 75. Institute of Archaeology, University of Oxford: 128-140. Oxford, UK.

Rivas Martínez S (1981) Les étages bioclimatiques de la végètation de la Peninsule Ibérique. Anales del Jardín Botánico de Madrid 37: 251-268.

Rosario IT do, Mathias M da L (2007) Post-fire recolonisation of a montado area by the endangered Cabrera vole (Microtus cabrerae). International Journal of Widland Fire 16: $450-457$.

Sala B, Locatelli E (2009) The Plio-Pleistocene access of terrestrial mammals to the Italian Peninsula. In: Fanti F, Spalletta C (eds) International Conference on Vertebrate Palaeobiogeography and Continental Bridges Across Tethys, Mesogea, and Mediterranean Sea, Abstract Book, 81-84. Bologna, Italia. 
Sala B, Masini F (2007) Late Pliocene and Pleistocene small mammal chronology in the Italian peninsula. Quaternary International 160: 4-16.

San Miguel Ayanz A (1992) Inventario de la Población Española de Topillo de Cabrera (Microtus cabrerae Thomas, 1906). Universidad Politécnica de Madrid, ICONA. Madrid, Spain.

Sánchez A, Jiménez J, Barbadillo LJ, Fraile S, Laplana C, Morales J et al. (2005) Primeros datos faunísticos del Neolítico madrileño: la Cueva de la Ventana (Torrelaguna, Madrid). In: Arias Cabal P, Ontañón R, García-Moncó C (eds) Actas del III Congreso del Neolítico de la Península Ibérica, 155-165. Santander, Spain.

Santos SM, Simoes MP, Mathias ML, Mira A (2006) Vegetation analysis in colonies of an endangered rodent, the Cabrera vole (Microtus cabrerae), in southern Portugal. Ecological Research 21: 197-207.

Sesé C (2006) Micromamíferos (Rodentia, Insectivora, Lagomorpha y Chiroptera) de la Peña de Estebanvela (Segovia). In: Cacho Quesada C, Ripoll López S, Muñoz Ibáñez FJ (eds) La Peña de Estebanvela (Estebanvela-Ayllón, Segovia). Grupos Magdalenienses en el Sur del Duero. Arqueología en Castilla y León 17: 145-166.

Sevilla P, Laplana C, Blain H-A, Colino F, Rodríguez R, Vega Toscano G (2009) Microvertebrados del nuevo yacimiento del Pleistoceno superior tardío del Abrigo del Monte (El Vellón, Madrid). In: Palmqvist P, Pérez-Claros JA (eds) Comunicaciones de 
las XXV Jornadas de la Sociedad Española de Paleontología, 263-267. Universidad de Málaga, Málaga, Spain.

Sommer RS, Nadachowski A (2006) Glacial refugia of mammals in Europe: evidence from fossil records. Mammal Review 36: 251-265.

Valenzuela S, Poitevin F, Cornette R, Bournery A, Nadal J, Vigne J-D (2009) Evolving ecosystems: ecological data from an Iron Age small mammals accumulation at Alorda Park (Catalonia, Spain). Journal of Archaeological Science 36: 1248-1255.

Valensi P, Bailon S, Michel V, Desclaux E, Rousseau L, Onoratini G, Genty D, Blamart D, de Lumley H (2007) Cadre climatique et environnemental des acheuléens de la grotte du Lazaret, à Nice. Données paléontologiques, biogéochimiques et radiométriques établies sur les faunes de vértébrés et d'invertébrés. ArchéoSciences, Revue d'Archéometrie 31: 137-150.

Vernet JL (1997) L’homme et la Forêt Méditerranéenne de la Préhistoire à nos Jours. Éditions Errance, Paris, France.

Vuletic A (1953) Brèche diluviale osseuse à Marjan. Biljeske 7: 1-3.

Watson J, Paz MA, Tusell M, Mañosa M (2004) Análisis arqueofaunístico. Campaña de 1988. In: Martín Socas D, Cámalich Massieu MD, González Quintero P (eds) La Cueva de El Toro (Sierra de El Torcal-Antequera-Málaga). Un Modelo de Ocupación 
Ganadera en el Territorio Andaluz entre el VI y II Milenios A.N.E., 215-266. Arqueología Monografías, Junta de Andalucía, Sevilla, Spain. 
Table 1. Length of the first lower molar in the Iberian Pleistocene and Holocene populations of Iberomys (only those with 5 specimens or more are included) and in recent populations of Microtus cabrerae from three different localities. Means, ranges (minimum and maximum values), standard deviations (SD) and samples sizes $(n)$ are shown. Data from: 1) Engels (1972); 2) Ayarzagüeña \& López Martínez (1976); 3) López Martínez (1980); 4) Ruiz Bustos et al. (1982); 5) Niethammer (1982); 6) Gil (1985); 7) Gil (1988); 8) Toni \& Molero (1990); 9) Gil (1997); 10) Laplana \& CuencaBescós (1998); 11) Cuenca-Bescós et al. (1999); 12) Denys (2000); 13) Jeannet (2000); 14) Ruiz Bustos (2000); 15) Povoas et al. (2005); 16) Barroso Ruiz et al. (2006); 17) López-García et al. (2008b); 18) Guillem Calatayud (2009); 19) Tormo Cuñat (2010); 20) López-García (2011); 21) Sesé et al. (2011a); 22) Sesé et al. (2011b); 23) Hanquet (2011); 24) Price (2012); 25) López-García et al. (2012); 26) authors' unpublished data. For complete bibliographic references, see Appendix S1. Localities from the same time interval have been arranged according to their chronological position whenever possible. A distinct size gap can be observed between the Middle Pleistocene populations assigned to Microtus brecciensis, with mean first lower molar lengths of less than $2.95 \mathrm{~mm}$, and the Late Pleistocene and Holocene populations assigned to Microtus cabrerae, with mean lengths greater than $3.04 \mathrm{~mm}$. 
Fig. 1. Chronological intervals used in this review to analyse changes in the geographic distribution of Microtus cabrerae . kyrBP $=$ thousand years before present.

Fig. 2. Variations in the density of records of Microtus cabrerae through time, from the Late Pleistocene to the present. $\mathrm{kyrBP}=$ thousand years before present. Values were obtained dividing the number of available records in each time interval (see Fig. 1) by its duration in thousands of years.

Fig. 3. Maps showing the geographic distribution of Microtus cabrerae records in each of the chronological intervals used in this paper (see Fig. 1); a) MIS5-4; b) MIS3; c) MIS2; d) Epipalaeolithic-Mesolithic; e) Neolithic; f) Chalcolithic-Bronze Age; g) Iron Age-Roman period; h) Middle Ages; i) Recent. In the lower right corner of each map, $\mathrm{n}$ indicates the number of Universal Transverse Mercator squares in which Microtus cabrerae was recorded.

Appendix S1. List of references including fossil records of Microtus cabrerae and used in the analysis.

Appendix S2. List of records of Microtus cabrerae during the Late Pleistocene, grouped according to the time intervals considered in this review.

Appendix S3. List of records of Microtus cabrerae during the Holocene, grouped according to the time intervals considered in this review. 


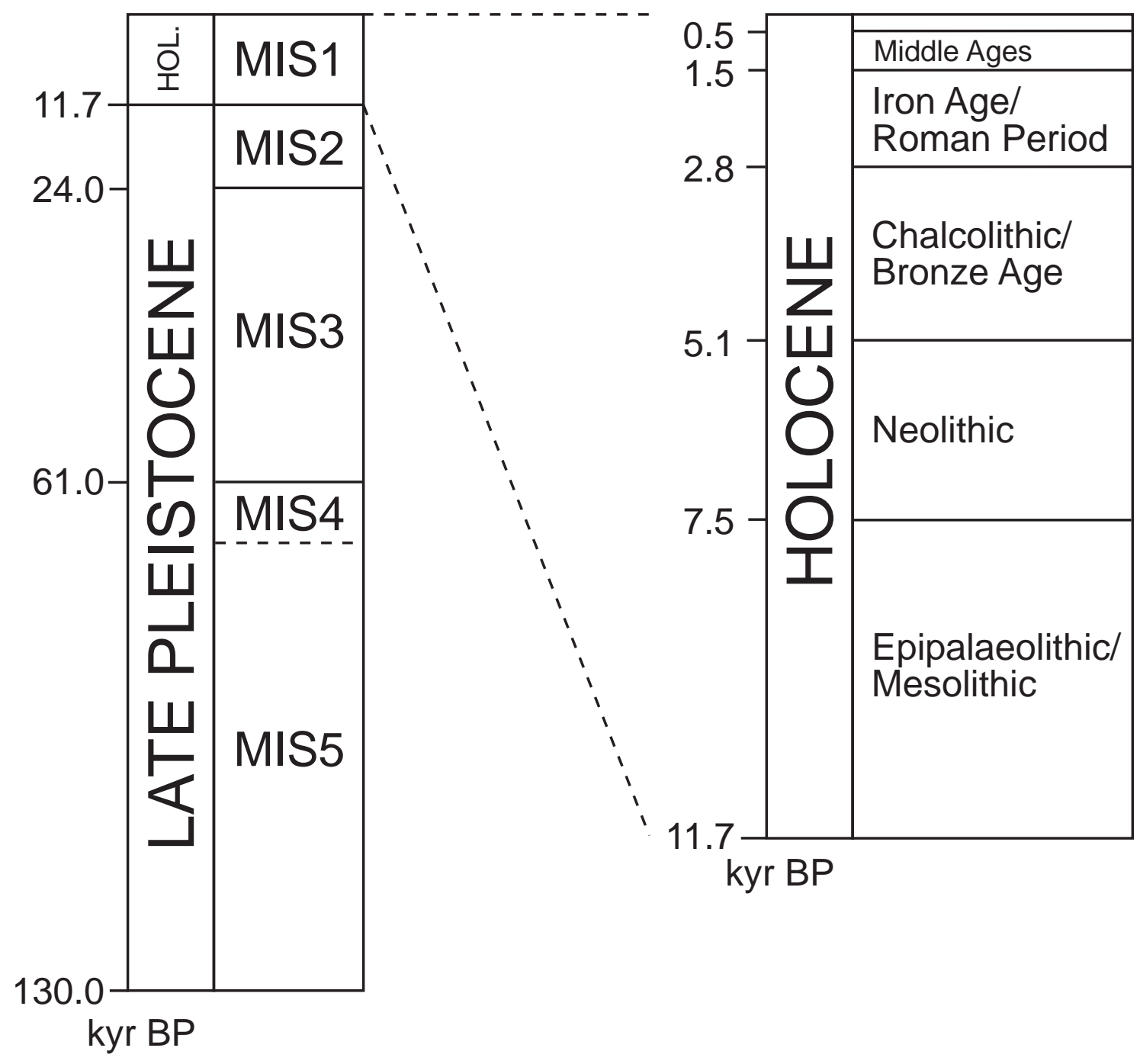




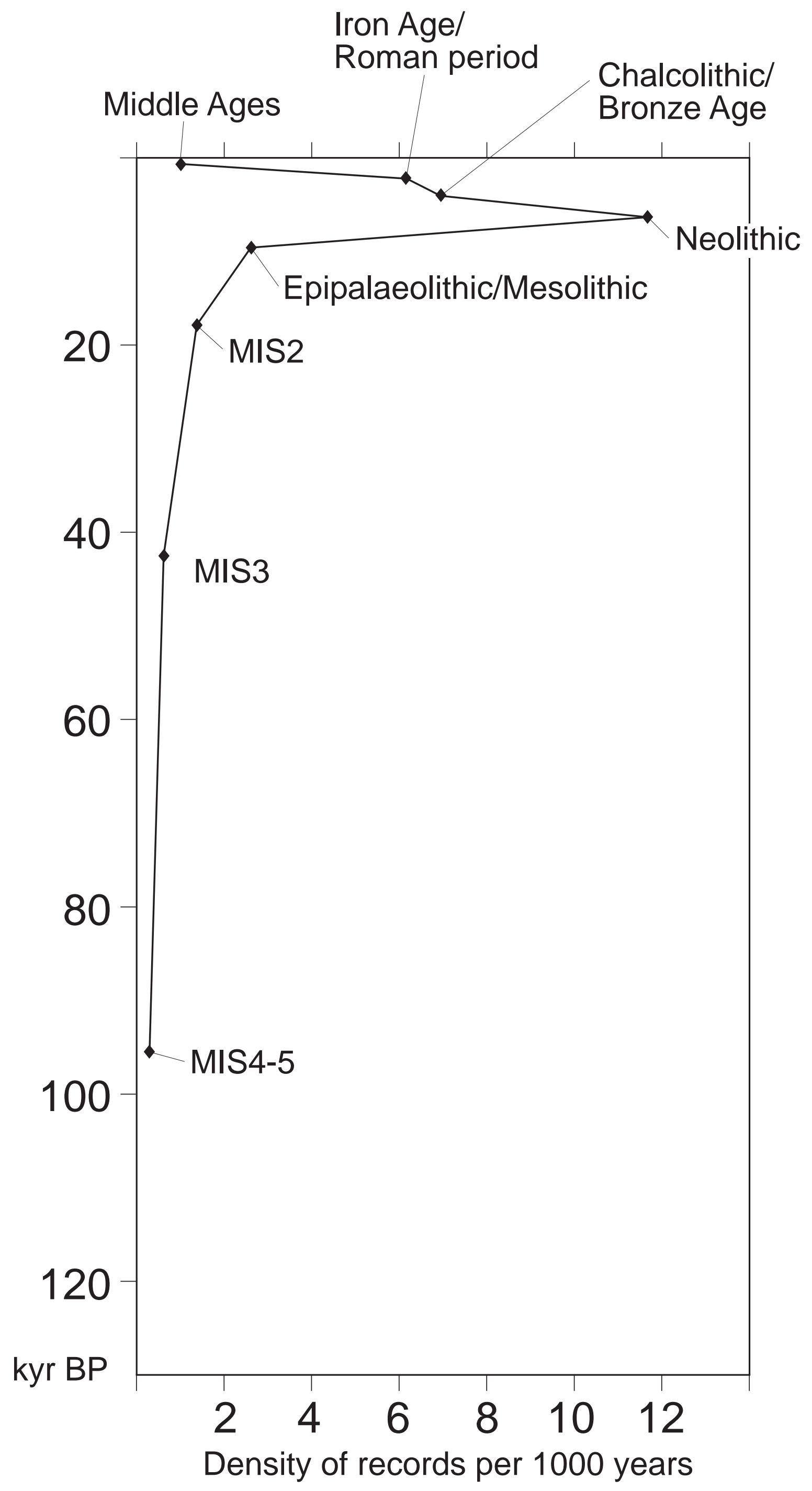




\begin{tabular}{|c|c|c|c|c|c|c|c|}
\hline \multirow{2}{*}{$\begin{array}{c}\text { Time } \\
\text { interval }\end{array}$} & \multirow{2}{*}{ Locality } & \multicolumn{5}{|c|}{ Length of the first lower molar } & \multirow{2}{*}{ Species } \\
\hline & & $\min$ & mean & $\max$ & SD & $\mathrm{n}$ & \\
\hline \multirow{3}{*}{ Recent } & Porto Covo (Portugal) $^{1}$ & 2.81 & 3.28 & 3.75 & 0.21 & 27 & \multirow{23}{*}{$\begin{array}{l}\text { Microtus } \\
\text { cabrerae }\end{array}$} \\
\hline & Cuenca $(\text { Spain })^{2}$ & 2.96 & 3.32 & 3.48 & 0.16 & 25 & \\
\hline & Sierra de Cazorla (Spain) ${ }^{5}$ & 2.75 & 3.04 & 3.35 & 0.21 & 8 & \\
\hline \multirow{4}{*}{ Holocene } & Valdetorres de Jarama (Spain) ${ }^{26}$ & 2.80 & 3.13 & 3.60 & 0.20 & 13 & \\
\hline & Cova del Toll (Spain) ${ }^{13}$ & 2.96 & 3.24 & 3.67 & 0.17 & 22 & \\
\hline & Cueva del Coscojar (Spain) ${ }^{6}$ & 2.80 & 3.24 & 3.76 & - & 29 & \\
\hline & Cova de les Cendres, Holoc. (Spain) ${ }^{18}$ & 2.95 & 3.28 & 3.70 & 0.05 & 13 & \\
\hline \multirow{16}{*}{$\begin{array}{c}\text { Late } \\
\text { Pleistocene }\end{array}$} & Portalón (Spain) ${ }^{20}$ & 3.00 & 3.10 & 3.25 & 0.13 & 5 & \\
\hline & Gruta do Caldeirao niv. K-E (Portugal) ${ }^{15}$ & 2.65 & 3.21 & 3.55 & 0.20 & 20 & \\
\hline & Cova de les Cendres, Gravet. (Spain) ${ }^{19}$ & 3.11 & 3.37 & 3.84 & - & 16 & \\
\hline & Cueva de las Graderas (Spain) ${ }^{7}$ & 2.86 & 3.25 & 3.68 & - & 58 & \\
\hline & Figueira Brava (Portugal) ${ }^{13}$ & 2.70 & 3.09 & 3.46 & 0.21 & 15 & \\
\hline & Devil's Tower (Gibraltar) ${ }^{12}$ & 3.13 & 3.43 & 3.63 & - & 9 & \\
\hline & Ibex Cave (Gibraltar) ${ }^{12}$ & 3.24 & 3.48 & 3.66 & - & 6 & \\
\hline & Gorham's Cave (Gibraltar) ${ }^{12}$ & 3.12 & 3.42 & 3.73 & - & 7 & \\
\hline & Gorham's Cave LBSmcf 2, 9, 11 (Gibraltar) ${ }^{24}$ & 2.79 & 3.26 & 3.80 & 0.24 & 41 & \\
\hline & Abric Romaní (Spain) ${ }^{20}$ & 3.00 & 3.35 & 3.72 & 0.19 & 25 & \\
\hline & Boquete de Zafarraya (Spain) ${ }^{16}$ & 2.81 & 3.28 & 3.64 & - & 93 & \\
\hline & Cova del Gegant (Spain) ${ }^{17}$ & 3.05 & 3.31 & 3.45 & 0.15 & 7 & \\
\hline & Gorham's Cave SSLm 2, 6 (Gibraltar) ${ }^{24}$ & 2.86 & 3.26 & 3.56 & 0.18 & 28 & \\
\hline & Cueva de la Carihuela lev. VII (Spain) ${ }^{14}$ & 2.73 & 3.10 & 3.51 & - & 11 & \\
\hline & Preresa (Spain) ${ }^{22}$ & 2.81 & 3.10 & 3.51 & - & 50 & \\
\hline & Pinilla del Valle (Spain) ${ }^{8}$ & 2.61 & 3.08 & 3.48 & - & 7 & \\
\hline \multirow{7}{*}{$\begin{array}{c}\text { Middle } \\
\text { Pleistocene }\end{array}$} & Sala de los Huesos (Spain) ${ }^{23}$ & 2.56 & 2.93 & 3.20 & 0.22 & 16 & \multirow{7}{*}{$\begin{array}{c}\text { Microtus } \\
\text { brecciensis }\end{array}$} \\
\hline & Valdocarros (Spain) ${ }^{21}$ & 2.67 & 2.88 & 3.17 & - & 17 & \\
\hline & Cueva del Agua (Spain) ${ }^{4}$ & 2.60 & 2.92 & 3.36 & - & 90 & \\
\hline & Trinchera Galería (Spain) ${ }^{11}$ & 2.42 & 2.86 & 3.26 & 0.28 & 9 & \\
\hline & Áridos-1 (Spain) ${ }^{3}$ & 2.32 & 2.79 & 3.18 & 0.24 & 44 & \\
\hline & TD8 (Spain) ${ }^{11}$ & 2.64 & 2.82 & 3.08 & - & 11 & \\
\hline & Cúllar de Baza-I (Spain) ${ }^{4}$ & 2.55 & 2.94 & 3.27 & - & 37 & \\
\hline Early & TD6 (Spain) ${ }^{10}$ & 2.35 & 2.69 & 3.04 & 0.13 & 171 & \multirow{2}{*}{$\begin{array}{c}\text { Microtus } \\
\text { huescarensis }\end{array}$} \\
\hline Pleistocene & El Chaparral (Spain) ${ }^{25}$ & 2.56 & 2.76 & 2.94 & 0.16 & 7 & \\
\hline
\end{tabular}

